\title{
Potential Combinations of Pasak Bumi (Eurycoma longifolia Jack), Docosahexaenoic Acid, and Seluang Fish (Rasbora spp.) to Improving Oxidative Stress of Rats (Rattus norvegicus) Brain Undernutrition
}

\author{
Didik Dwi Sanyoto $^{1}$ D , Meitria Syahadatina Noor $^{2 *}$ (D) Triawanti Triawanti $^{3}$ D \\ ${ }^{1}$ Department of Biomedical, Division of Anatomy, Faculty of Medicine, Universitas Lambung Mangkurat, Banjarmasin, Indonesia; \\ ${ }^{2}$ Department of Public Health, Faculty of Medicine, Universitas Lambung Mangkurat, Banjarmasin, Indonesia; ${ }^{3}$ Department of \\ Biochemistry and Biomolecular, Faculty of Medicine, Universitas Lambung Mangkurat, Banjarmasin, Indonesia
}

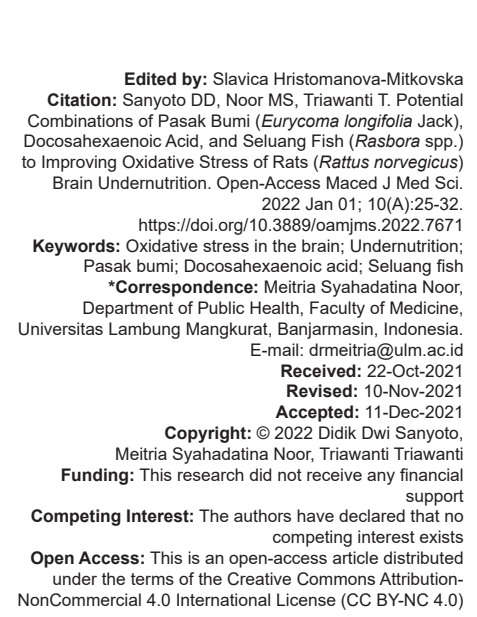

\section{Introduction}

Brain cells require a constant supply of oxygen and nutrients for homeostasis and are very sensitive to the slightest changes in oxygen and nutrient levels. During the growth period, the brain is susceptible to nutritional deficiencies that result in brain dysfunction. Nutrients have major effects during the late fetal, neonatal, and first 1000 days of life, including protein, iron, zinc, selenium, iodine, folate, Vitamin A, choline, and long-chain polyunsaturated fatty acids (PUFAs). The onset, dose, duration, and type of nutritional deficiency affect the effects on the brain.

The brain is highly susceptible to damage from oxidative stress due to its high metabolic activity. This is because the brain requires large amounts of molecular oxygen, resulting in high levels of free radicals. The brain also contains PUFAs which are highly oxidized [1].
In addition, the total antioxidant capacity of the central nervous system is relatively small. Increased oxidative stress can also be caused by a deficiency of calories, protein, and micronutrient intake [2]. Oxidative stress in the brain causes damage to cell membranes which, in turn, can reduce brain function.

Protein deficiency will interfere with the synthesis of enzymes that act as antioxidants and reduce the concentration of antioxidants in the tissue, causing a state of antioxidant deficiency and oxidative stress in the brain [3]. Triawanti et al. (2017) proved that in the brains of undernourished rats, there was an increase in hydrogen peroxide $\left(\mathrm{H}_{2} \mathrm{O}_{2}\right)$ and malondialdehyde (MDA) levels. $\mathrm{H}_{2} \mathrm{O}_{2}$ is a reactive oxygen species (ROS) while MDA is a product of lipid membrane damage due to oxidative reactions [4].

Provision of nutrients and compounds that can act as antioxidants is needed in conditions of protein deficiency to cope with excessive oxidative stress in 
the brain. Triawanti et al. (2017) research proved that giving seluang fish (Rasbora spp.) to rats lacking protein calories can reduce $\mathrm{H}_{2} \mathrm{O}_{2}$ and MDA levels. Seluang fish contain the amino acid which is needed for the formation of the enzymatic antioxidant. In addition, seluang fish contain docosahexaenoic acid (DHA) which has the potential as an antioxidant [4]. The research of Sanyoto et al. (2019) proved that giving DHA to protein-deficient mice could increase the SOD enzyme and reduce MDA levels in the blood [5]. DHA can reduce ROS-induced DNA damage in aortic endothelial cells and reduce $\mathrm{H}_{2} \mathrm{O}_{2}$ [6]. In addition to providing adequate nutrition, research has proven that administration of $70 \%$ ethanol extract of pasak bumi can reduce oxidative stress in the brain of undernourished rats [7]. However, there has been no research on the combination of pasak bumi, seluang fish as a source of protein, and DHA which strengthens the antioxidant effect in the brain. This study was conducted with the aim of proving the potential of the combination of pasak bumi, seluang fish, and DHA as an antioxidant in the brains of undernourished rats.

\section{Methods}

This research has received ethical approval from the Health Research Ethics Commission, Faculty of Medicine, Lambung Mangkurat University, with the number 061/KEPK-FK UNLAM/EC/II/2020.

\section{Materials}

Pasak bumi root, seluang fish, pure DHA, lowprotein feed (AIN-76A, Purified rodent diet [Dyets Inc., USA] casein $60 \mathrm{~g} / \mathrm{kg}$, DL-methionine $0.9 \mathrm{~g} / \mathrm{kg}$, sucrose $609.1 \mathrm{~g} / \mathrm{kg}$, cornstarch $183 \mathrm{~g} / \mathrm{kg}$, corn oil $50 \mathrm{~g} / \mathrm{kg}$, cellulose $50 \mathrm{~g} / \mathrm{kg}$, mineral mix\#200000 $35 \mathrm{~g} / \mathrm{kg}$, vitamin mix \#300050 $10 \mathrm{~g} / \mathrm{kg}$, and choline bitartrate $2 \mathrm{~g} / \mathrm{kg}$ ), standard feed (protein 20-22\%, fat $5-7 \%$, fiber 3-5\%, cinder $5-7 \%$, calcium $9-11 \%$, phosphorus $0.6-0.8 \%$, and energy 2900-3100 kcal), aquadest, $70 \%$ ethanol, $90 \%$ ethanol, Rattus norvegicus rats, FeCl2 $2 \mathrm{mM}$, o-phenanthroline, $\mathrm{H}_{2} \mathrm{O}_{2} 40 \mathrm{mM}$, PBS pH 7.4, aquadest, $\mathrm{HCl} 2,5 \mathrm{M}, 2 \%$ glucose, $\mathrm{NaCl} 0.9 \%, \mathrm{Na}_{2} \mathrm{CO}_{3}$, standard MDA, trichloroacetic acid (TCA), thiobarbituric acid, $\mathrm{HCl} 1 \mathrm{~N}$, acetic acid, and $\mathrm{K}_{2} \mathrm{Cr}_{2} \mathrm{O}_{7}$.

\section{Procedures} malnutrition

Preparation of experimental animal

Rat pups were made undernourished from the day they were born by feeding the rat's mother that was breastfeeding at satiation with low-protein feed (AIN$76 \mathrm{~A}, 6 \%$ protein), for 4 weeks, after weaning the rat pups continued with low-protein feed (AIN-76A) for 4 weeks. Totally, rat pups received low-protein feed for 8 weeks (56 days). Rats were classified as undernourished if the serum protein level was below $4.7 \mathrm{~g} / \mathrm{dL}$. Blood was taken from the tail vein as much as $1 \mathrm{~mL}$, centrifuged, and then the serum protein level was measured. $R$. norvegicus normal protein level is $4.7-5.2 \mathrm{~g} / \mathrm{dL}$ [4].

\section{Administration of the ethanol extract $70 \%$} pasak bumi root (EPB), seluang fish, and DHA

Once the rats were undernourished, they were divided into six groups, namely, positive control (KP): Undernourished rats + placebo + standard feed; $(P 1)$ : Undernourished rats $+70 \%$ EPB $15 \mathrm{mg} / \mathrm{kg}+$ standard feed; (P2): Undernourished rats + DHA $1 \mathrm{mg} / \mathrm{kg}$ body weight $(\mathrm{BW})+$ standard feed; (P3): Undernourished rats + EPB $15 \mathrm{mg} / \mathrm{kg} \mathrm{BW}+\mathrm{DHA} 1 \mathrm{mg} / \mathrm{kg} \mathrm{BW}+$ standard feed; (P4): Undernourished rats + seluang fish; (P5): Undernourished rats + EPB $15 \mathrm{mg} / \mathrm{kg} \mathrm{BW} \mathrm{+} \mathrm{seluang}$ fish for 5 weeks; and plus 1 negative control group (KN) that is healthy rats given placebo and standard feed for 5 weeks. Each group consisted of five rats. The use of EPB at a dose of $15 \mathrm{mg} / \mathrm{kg} \mathrm{BW}$ based on the results of the previous studies which showed the best antioxidant potential compared to a dose of $7.5 \mathrm{mg} / \mathrm{kg} \mathrm{BW} \mathrm{[7].}$

\section{$\mathrm{H}_{2} \mathrm{O}_{2}$, catalase, and MDA levels assay from brain homogenate}

After 5 weeks of intervention, the rat's brain was taken by means of the rat sacrificed using anesthetic drugs, then blood was taken from the heart. After the rat was declared dead, the brain was taken immediately by opening the rat's skull. All parts of the cerebrum were taken to be made into a homogenate. The brain was pounded with mortar at room temperature and added with $1 \mathrm{~mL}$ of phosphate-buffered saline (PBS) $\mathrm{pH} 7.4$ until it became liquid. Then taken $5 \mathrm{~mL}$ and centrifuged at $8000 \mathrm{rpm}$ for $20 \mathrm{~min}$. The supernatant was then taken for the measurement of $\mathrm{H}_{2} \mathrm{O}_{2}$ [8], SOD [9], catalase [10], and MDA by thiobarbituric acid method.

\section{Measurement of brain SOD activity}

Mix of the $3 \mathrm{~mL}$ of $0.05 \mathrm{M} \mathrm{Na}_{2} \mathrm{CO}_{3}$ and $1 \mathrm{M}$ EDTA pH 10.2 were incubated at $30^{\circ} \mathrm{C}$, then $100 \mathrm{~L}$ brain homogenate and $100 \mathrm{~L}$ adrenaline were added. Then, the absorption was measured at a wavelength of $480 \mathrm{~nm}$ as Ao. After that, the solution was incubated for $5 \mathrm{~min}$ at $30^{\circ} \mathrm{C}$ and the absorbance (A1) was measured.

\section{Measurement of brain $\mathrm{H}_{2} \mathrm{O}_{2}$ levels}

The first step is to make standard curves of $\mathrm{H}_{2} \mathrm{O}_{2}$ absorbance at concentrations of $20,40,60,80$, $100,120,140,160$, and 180 mol. A graph was made 
between the absorbance on the $\mathrm{Y}$-axis with levels of $\mathrm{H}_{2} \mathrm{O}_{2}$ on the $\mathrm{X}$-axis to obtain a linear equation. Furthermore, as much as $1 \mathrm{~mL}$ of brain homogenate was added $5 \mathrm{~mL}$ of PBS $\mathrm{pH} 7.4$. Then take $1 \mathrm{~mL}$ of the mixture, add $2 \mathrm{~mL}$ of dichromate: acetate (1:3) mixture and then wrapped in aluminum foil for $30 \mathrm{~min}$. The mixed solution was heated using a water bath for $10 \mathrm{~min}$ at $100^{\circ} \mathrm{C}$. The solution was cooled to room temperature. The solution was then transferred into the cuvette and measured its absorbance using ultraviolet-visible at a wavelength of $570 \mathrm{~nm}$. To calculate the levels of $\mathrm{H}_{2} \mathrm{O}_{2}$, a linear regression equation formula is used from the absorbance results on the standard curve made, namely: $y=a x+b$. In this study, the linear regression equation formula $y=53,782 x+(-0.1434)$ was obtained. $\mathrm{x}=$ absorbance at a wavelength of $570 \mathrm{~nm}$.

\section{Measurement of catalase activity}

Catalase activity was determined by the Aebi method [10]. A total of $0.1 \mathrm{~mL}$ of brain homogenate supernatant were added to a cuvette containing $1.9 \mathrm{~mL}$ of $50 \mathrm{mM}$ phosphate buffer $\mathrm{pH}$ 7.0. The new reaction was started with the addition of $1.0 \mathrm{~mL}$ $\mathrm{H}_{2} \mathrm{O}_{2} 30 \mathrm{mM}$. The reaction occurs immediately after the addition of $\mathrm{H}_{2} \mathrm{O}_{2}$. Read the first absorbance (A1) after $15 \mathrm{~s}(\mathrm{t} 1)$ and the second absorbance (A2) after $30 \mathrm{~s}$ (t2). The absorbance was read at a wavelength of $240 \mathrm{~nm}$. Catalase activity was expressed as units/ $\mathrm{mg}$ protein. One unit is defined as a constant velocity per second. The results obtained are entered in the formula:

$$
\begin{gathered}
\mathrm{K}=\frac{\text { Total volume } \times 2.3}{\text { Sample volume } \times \Delta t} \times \log \frac{\mathrm{A} 1}{\mathrm{~A} 2} \\
\text { Unit / } \mathrm{mg} \text { protein }=\frac{\mathrm{K}}{\mathrm{mg} \text { protein }}
\end{gathered}
$$

\section{Measurement of brain MDA levels}

The first step was to make standard curves of MDA concentrations of $0.05,0.025,0.0125,0.00625$, 0.003125 , and $1.56 \times 10^{-5} \mathrm{M}$. Then making graphs for the relationship between absorbance on the Y-axis and MDA levels on the X-axis to obtain a linear equation. A further $200 \mathrm{~L}$ supernatant was taken for the measurement of MDA levels. Thereafter, $100 \mathrm{~L}$ of $100 \%$ TCA, $100 \mathrm{~L}$ sodium thiobarbituric $1 \%$, and $250 \mathrm{~L}$ $\mathrm{HCl} 1 \mathrm{~N}$ were added, respectively. Then heated at $100^{\circ} \mathrm{C}$ for $20 \mathrm{~min}$ and centrifuged $3500 \mathrm{rpm}$ for $10 \mathrm{~min}$. Subsequently, $450 \mathrm{~L}$ supernatant was taken and the distilled water added to $3500 \mathrm{~L}$. Then read with the spectrophotometer with a maximum wavelength of $540 \mathrm{~nm}$.

\section{Data analysis}

Normality test using Shapiro-Wilk. If normal, proceed with the ANOVA test analysis with a 95\% confidence level and a Tukey HSD test. If it is not normal, then a Kruskal-Wallis non-parametric test is followed by Mann-Whitney with a $95 \%$ confidence level. Test statistics using online statistical software provided at the link https://stats.blue.

\section{Results}

\section{Superoxide dismutase (SOD) activity}

The results of the average activity of the SOD enzyme are shown in Figure 1. It can be seen that the control group (KN) has the highest SOD activity compared to other groups, while the lowest activity is shown by the positive control group (KP). Among the groups that were given the intervention of pasak bumi extract, DHA, and seluang and their combination, it was seen that the group given the combination of seluang and EPB $15 \mathrm{mg} / \mathrm{kg}$ BW had the same high SOD activity as the P3 group.

The Kruskal-Wallis test was carried out to obtain $p=0.001$, meaning that there was a significant difference in SOD activity between groups. Furthermore, the Mann-Whitney U-test was carried out to determine the differences between each group. There was a significant difference between the $\mathrm{KN}$ group and the $\mathrm{KP}, \mathrm{P} 1, \mathrm{P} 2$, and P4 groups. Meanwhile, the KP group was also significantly different from $\mathrm{P} 1, \mathrm{P} 3$, and $\mathrm{P} 5$. Furthermore, P2 was significantly different from P5, $\mathrm{P} 3$ to $\mathrm{P} 4$, and P4 to P5. The SOD activity in the P5 group was not significantly different from that in the $\mathrm{KN}$ and P3 groups, which indicated that the combination administration of seluang fish and EPB $15 \mathrm{mg} / \mathrm{kg} \mathrm{BW}$ and the combination of DHA $1 \mathrm{mg} / \mathrm{kg} \mathrm{BW}$ and EPB $15 \mathrm{mg} / \mathrm{kg}$ BW were able to increase SOD activity so that it was not different from normal rats.

\section{Peroxide levels}

The average levels of peroxide $\left(\mathrm{H}_{2} \mathrm{O}_{2}\right)$ are shown in Figure 2. In the P3 and P5 groups, the peroxide levels were lower than the other groups. The results of the Kruskal-Wallis statistical test showed that there was a significant difference in peroxide levels in the treatment group ( $p=0.000$ ). Furthermore, the Mann-Whitney $U$-test was carried out, the results showed that there were differences between the control group $(\mathrm{KN})$ and $\mathrm{KP}, \mathrm{P} 1$, P2, P3, P4, and P5. Meanwhile, the positive control group (KP) was significantly different from P3, P4, and P5, while $\mathrm{P} 1$ was significantly different from $\mathrm{P} 2, \mathrm{P} 3, \mathrm{P} 4$, and $\mathrm{P} 5$. The P2 group was significantly different from P5, the P3 group was significantly different from P4, while P4 was 


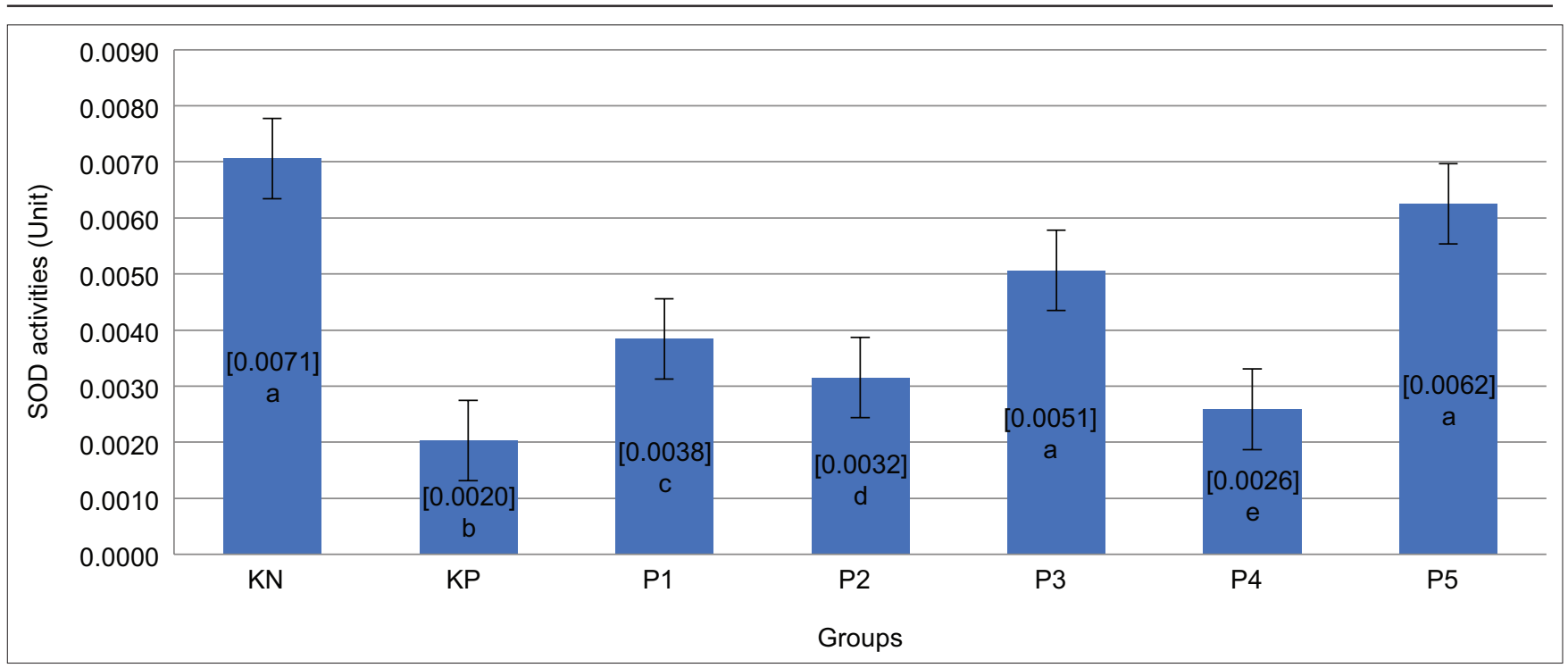

Figure 1: Mean superoxide dismutase activity of undernutrition rat brain after intervention $(K N=$ Normal rat, $K P=$ Undernutrition + placebo, $P 1$ = Undernutrition + ethanol extract pasak bumi root $[E P B] 15 \mathrm{mg} / \mathrm{kg}$ body weight [BW], $P 2=$ Undernutrition + docosahexaenoic acid [DHA] 1 $\mathrm{mg} / \mathrm{kg} B W, P 3=$ Undernutrition + DHA $1 \mathrm{mg} / \mathrm{kg} B W+E P B 15 \mathrm{mg} / \mathrm{kg} B W, P 4=$ Undernutrition + seluang, and P5 = Undernutrition + seluang + $E P B 15 \mathrm{mg} / \mathrm{kg} B W, E P B=70 \%$ ethanol extract of pasak bumi, $p=0.001$; the same superscript letter shows no significant difference)

significantly different from P5. There was no significant difference between P3 and P5 which had low peroxide levels. This shows that the administration of DHA and EPB $15 \mathrm{mg} / \mathrm{kg}$ BW has the same potential as the administration of seluang and EPB $15 \mathrm{mg} / \mathrm{kg}$ BW in reducing peroxide levels in the brains of undernourished rats.

\section{Catalase activity}

The mean brain catalase enzyme activity of undernourished rats after the intervention is shown in Figure 3. It can be seen that in the positive control group (KP), rats that were undernourished and fed only standard diet + placebo showed low catalase activity. Meanwhile, the $\mathrm{P} 3$ group which was given a combination of DHA $1 \mathrm{mg} / \mathrm{kg}$ BW and EPB $15 \mathrm{mg} / \mathrm{kg}$ BW showed the highest catalase activity compared to other groups. The results of Kruskal-Wallis statistical tests showed that there was a significant difference between the treatment groups with $p=0.000$. The Mann-Whitney follow-up test showed that there were significant differences between the KN groups with KP, P1, P3, P4, and P5. For the KP group, it was significantly different from all groups, while P1 was not significantly different from P4 and P5. Groups P2 and P3 were significantly different from all groups except $P 2$, not significantly different from $\mathrm{KN}$. This proves that the combination of DHA $1 \mathrm{mg} / \mathrm{kg}$ BW and EPB $15 \mathrm{mg} / \mathrm{kg}$ BW has the highest potential to increase catalase activity.

\section{Malondialdehyde levels}

The results of the mean levels of MDA are shown in Figure 4. Based on Figure 4, it can be seen

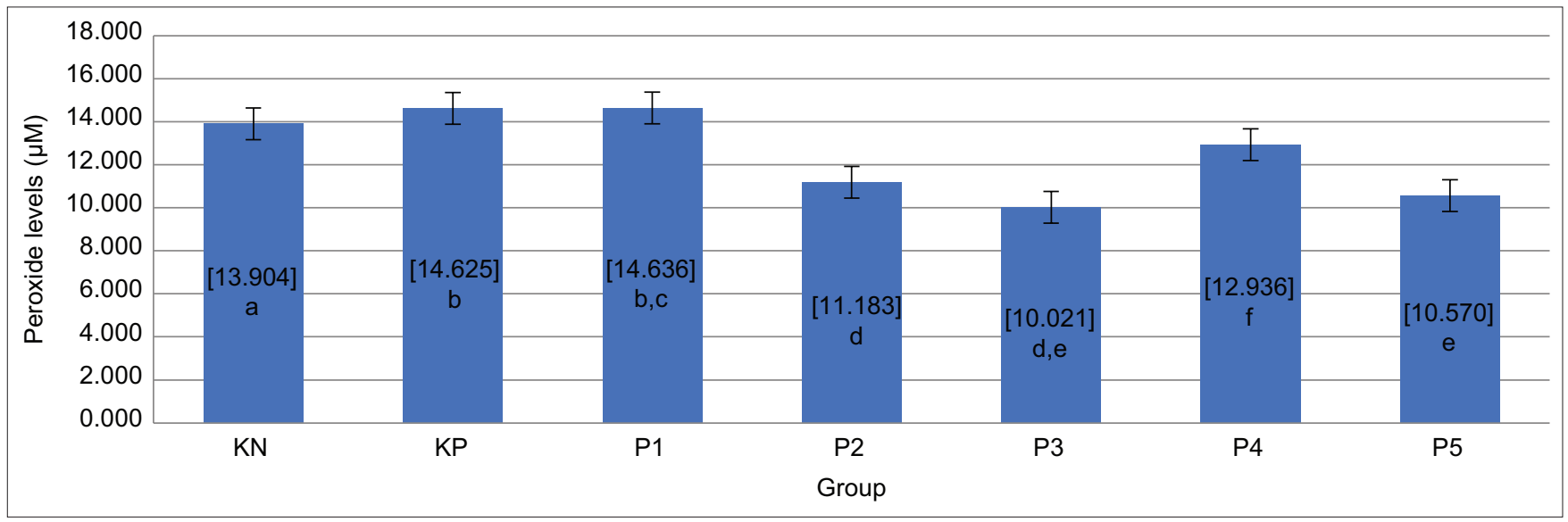

Figure 2: Mean levels of peroxide $(\mathrm{H} 2 \mathrm{O} 2)$ in undernourished rat brain after intervention $(K N=N o r m a l$ rat, $K P=U n d e r n u t r i t i o n+p l a c e b o, P 1=$ Undernutrition + ethanol extract pasak bumi root [EPB] $15 \mathrm{mg} / \mathrm{kg}$ body weight [BW], P2 = Undernutrition + docosahexaenoic acid [DHA] $1 \mathrm{mg} /$ $\mathrm{kg} B W, P 3=$ Undernutrition + DHA $1 \mathrm{mg} / \mathrm{kg} \mathrm{BW}+E P B 15 \mathrm{mg} / \mathrm{kg} \mathrm{BW}, P 4=$ Undernutrition + seluang, and P5 = Undernutrition + seluang + EPB $15 \mathrm{mg} / \mathrm{kg} B W, E P B=70 \%$ ethanol extract of pasak bumi, $p=0.000$. The same superscript letter shows no significant difference) 


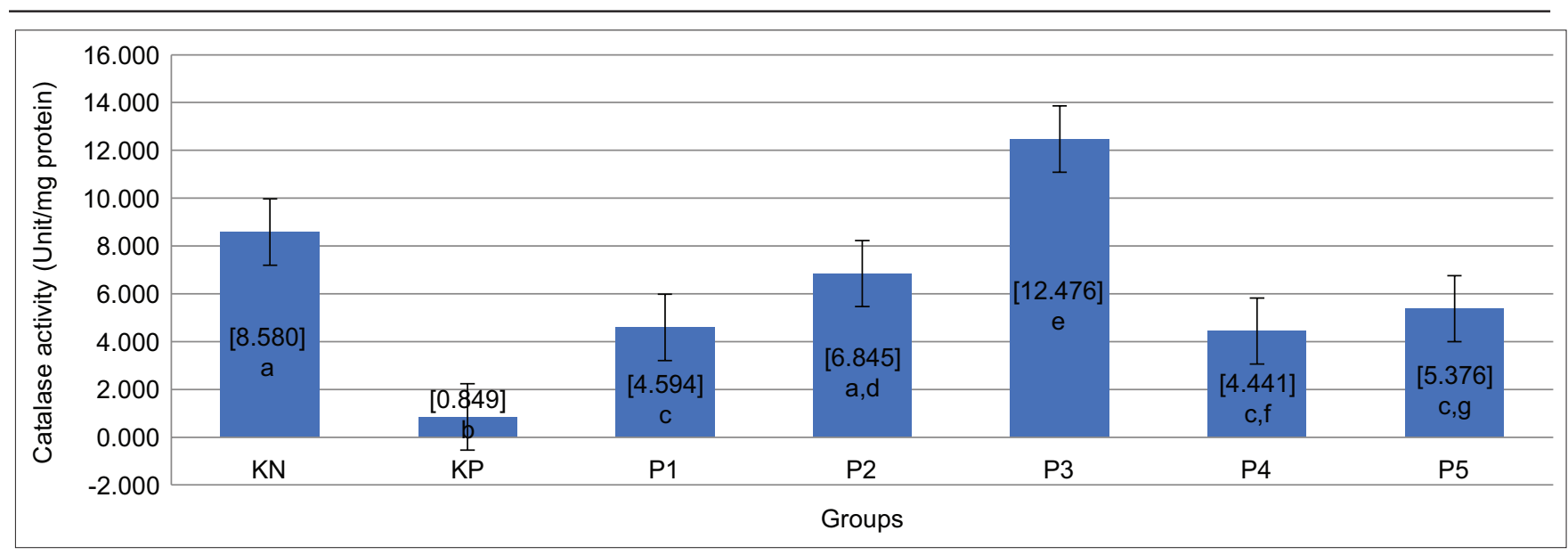

Figure 3: Mean catalase activity of undernourished mice after intervention $(K N=$ Normal mice, $K P=$ Undernutrition + placebo, $P 1=$ Undernutrition + ethanol extract pasak bumi root [EPB] $15 \mathrm{mg} / \mathrm{kg}$ body weight $[B W], P 2=$ Undernutrition + docosahexaenoic acid [DHA] $1 \mathrm{mg} / \mathrm{kg} B W, P 3=$ Undernutrition + DHA $1 \mathrm{mg} / \mathrm{kg} B W+E P B 15 \mathrm{mg} / \mathrm{kg} B W, P 4=$ Undernutrition + seluang, and $P 5=$ Undernutrition + seluang + EPB $15 \mathrm{mg} / \mathrm{kg}$ $B W, E P B=70 \%$ ethanol extract of pasak bumi, $p=0.000$ )

that the positive control group (KP) had the highest MDA levels than other groups. Meanwhile, the P1 and P3 groups had almost the same MDA levels as the control group. The Kruskal-Wallis test was used which proved that there was a significant difference in the treatment group $(p=0.000)$. The Mann-Whitney follow-up test was used to see the differences in each group. The results of the Mann-Whitney U-test showed that there was a difference between the $\mathrm{KN}$ group and $K P, P 2$, and $P 4$, while the KP group was significantly different from all groups. MDA levels in the P1 group were significantly different from $\mathrm{P} 2$ and $\mathrm{P} 4$, while $\mathrm{P} 2$ was significantly different from $\mathrm{P} 3$. The $\mathrm{P} 3$ group was significantly different from P4 and the P4 group was significantly different from $P 5$. This proves that the combination of DHA $1 \mathrm{mg} / \mathrm{kg}$ BW and EPB $15 \mathrm{mg} / \mathrm{kg}$ $\mathrm{BW}$ as well as the combination of seluang fish and EPB $15 \mathrm{mg} / \mathrm{kg}$ BW can reduce MDA levels in the brains of undernourished rats.

\section{Discussion}

The brain is an organ that is very susceptible to damage due to oxidative stress. This happens because the brain requires high oxygen, contains iron and copper which are cofactors for oxidative reactions, and PUFAs that are easily oxidized. Highly reactive ROS can chemically modify lipids, proteins, and nucleic acids, which initiate pathomechanisms of cell injury. Neurons in certain parts of the brain are particularly susceptible to ROS, namely, the CA1 hippocampus area and the cerebral granule cell layer [11]. Excessive of ROS causes neuronal cell damage and induces death through the apoptotic and necrotic pathways. There is a link between oxidative stress and mitochondrial dysfunction and the development of cell death in various neurological disorders. Mitochondrial dysfunction includes bioenergetic failure and increased cytosolic calcium, oxidative stress, mitochondrial permeability transition pore opening, and release of key proteins into cells triggering cell death [12]. This can have a negative impact on learning abilities and memory.

Oxidative stress can be triggered by undernutrition. Research by Perampelli et al. (2010) proved that in kwashiorkor, marasmus, and marasmic kwashiorkor, there was an increase in MDA and NO. levels in their respective blood compared to controls. Elevated MDA levels indicate a lipid peroxidation reaction in an inadequate protein diet. Lipid peroxidation can cause cellular damage anywhere including brain cells. In kwashiorkor, frequent infections stimulate NO synthase activity. Oxidative stress and nitrosative stress are closely linked and NO as a vasoactive and potentially toxic metabolite may contribute to the pathophysiology of kwashiorkor in malnutrition [13].

In this study, it was seen that in the undernutrition group (KP), oxidative stress occurred in the brain, namely, an imbalance between antioxidants and reactive oxygen compounds (ROS). In the KP group, the SOD and catalase enzymatic antioxidant activities were the lowest compared to other groups (Figures 1 and 3 ), while the levels of peroxide (Figure 2) and MDA (Figure 4) were higher than other groups. This is in line with the research of Triawanti et al. (2017) which proved that in the brains of undernourished rats show an increase in $\mathrm{H}_{2} \mathrm{O}_{2}$ and MDA levels. Protein deficiency causes a decrease in the synthesis of enzymes, including those that act as enzymatic antioxidants, resulting in an increase in free radicals. In addition, a low intake of amino acids reduces the synthesis of albumin and immunoglobulins, thereby increasing the risk of infection and increasing phagocytic activity which results in increased free radicals [13]. 


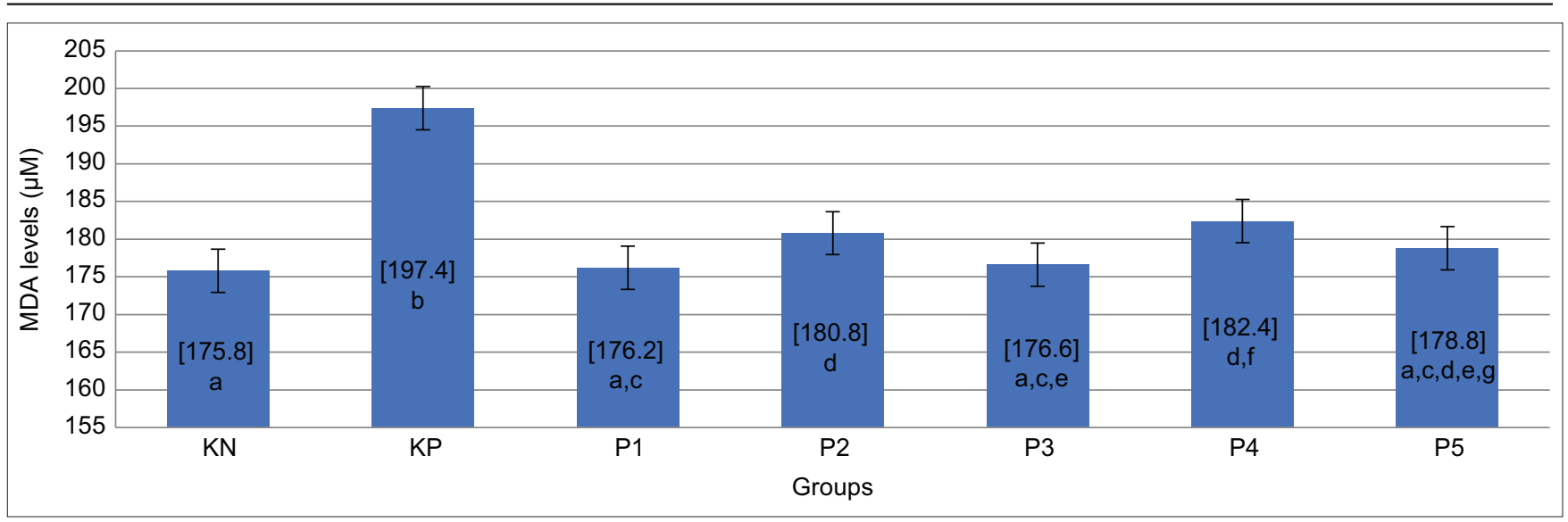

Figure 4: Mean brain malondialdehyde levels of undernourished rats after intervention $(K N=$ Normal rats, $K P=U n d e r n u t r i t i o n+$ placebo, $P 1=$ Undernutrition + ethanol extract pasak bumi root [EPB] $15 \mathrm{mg} / \mathrm{kg}$ body weight [BW], P2 = Undernutrition + docosahexaenoic acid [DHA] $1 \mathrm{mg} /$ $\mathrm{kg} \mathrm{BW}, P 3=$ Undernutrition + DHA $1 \mathrm{mg} / \mathrm{kg} \mathrm{BW}+E P B 15 \mathrm{mg} / \mathrm{kg} \mathrm{BW}, P 4=$ Undernutrition + cellulosic, and P5 = Undernutrition + cellulosic + $E P B 15 \mathrm{mg} / \mathrm{kg} \mathrm{BW}, E P B=70 \%$ ethanol extract of pasak bumi, $p=0.000$; the same superscript letter showed no significant difference)

In this study, several interventions were given to overcome oxidative stress in the brains of undernourished rats. The intervention given was in the form of a single administration of EPB $15 \mathrm{mg} / \mathrm{kg} \mathrm{BW}$, DHA $1 \mathrm{mg} / \mathrm{kg} \mathrm{BW}$, seluang fish, or a combination of EPB $15 \mathrm{mg} / \mathrm{kg}$ BW and DHA $1 \mathrm{mg} / \mathrm{kg} \mathrm{BW}$, and EPB $15 \mathrm{mg} /$ $\mathrm{kg} \mathrm{BW}$ and seluang fish. Based on Figures 1 and 3, it can be seen that the group given EPB $15 \mathrm{mg} / \mathrm{kg}$ BW and DHA $1 \mathrm{mg} / \mathrm{kg}$ BW showed the highest activity of SOD and catalase enzymes compared to other groups. In addition, Figures 2 and 4 also show that the $\mathrm{P} 3$ group had lower levels of peroxide and MDA than the other groups.

SOD and catalase are antioxidant enzymes as a defense against free radicals. SOD converts superoxide radicals into $\mathrm{H}_{2} \mathrm{O}_{2}$ which is then converted into $\mathrm{H}_{2} \mathrm{O}$ and $\mathrm{O}_{2}$ by the catalase enzyme. This study proved that the administration of $15 \mathrm{mg} / \mathrm{kg} \mathrm{BW}$ of EPB and $1 \mathrm{mg} / \mathrm{kg}$ BW of DHA was able to increase the activity of SOD and catalase. Pasak bumi used in this study contains flavonoid compounds of $42.28 \mathrm{mg} / \mathrm{mL}$ which act as antioxidants [7]. Flavonoids can reduce oxidative stress through mechanisms (1) directly as ROS scavengers; (2) chelating free radicals by donating hydrogen atoms or by single-electron transfer; (3) chelation of transition metal elements; (4) inhibiting enzymes that generate free radicals; and (5) induces other internal antioxidant enzymes [14]. Triawanti et al. proved that the $15 \mathrm{mg} / \mathrm{kg}$ BW ethanol extract of pasak bumi has the potential to increase enzymatic antioxidant activity higher than the dose of $7.5 \mathrm{mg} / \mathrm{kg} \mathrm{BW}$ [7].

Figures 1 and 3 show that the group that was given a combination of EPB $15 \mathrm{mg} / \mathrm{kg} \mathrm{BW}$ and DHA $1 \mathrm{mg} / \mathrm{kg}$ BW had the highest SOD and catalase activity compared to the group that was only given EPB $15 \mathrm{mg} / \mathrm{kg} \mathrm{BW}$, DHA $1 \mathrm{mg} / \mathrm{kg}$ BW, and seluang fish significantly. This proves that $1 \mathrm{mg} / \mathrm{kg} \mathrm{BW}$ of $\mathrm{DHA}$ is able to strengthen the potency of pasak bumi, because if only $15 \mathrm{mg} / \mathrm{kg} \mathrm{BW}$ of EPB was given, the activity of SOD and catalase was lower. The ethanol extract of pasak bumi can increase the activity of SOD and catalase through an indirect mechanism. The content of flavonoids in pasak bumi has a structure $\mathrm{C} 2=\mathrm{C} 3$ double bond in conjugation with a 4-carbonyl group in ring $\mathrm{C}$. The presence of a $\mathrm{C} 2=\mathrm{C} 3$ double bond in conjugation with a 4-carbonyl group plays an assisting role in antioxidant activity. In general, position and number of hydroxylation correlate reasonably to antioxidation of flavonoids. Hydrogens and electrons are donated by ring $B$ hydroxyl groups to hydroxyl, peroxyl, and peroxynitrite radicals, forming relatively stable flavonoid radicals. On the other side, flavonoids could scavenge the resulting radicals to neutralize the prior effect. Almost total radical scavenging ability has been attributed to C-glycosyl flavonoids rather than O-glycosides [15]. With this structure, it can reduce the reactivity of free radicals including superoxide, hydroxyl, and peroxide radicals. Excessive free radicals cause damage to various molecules including proteins that act as enzymatic antioxidants. In this study, it was proven that in the malnutrition group, there was an increase in peroxide and MDA as well as a decrease in SOD and catalase. By decreasing free radicals, the damage to enzymatic antioxidant proteins can be reduced and their activity increased.

DHA is a PUFA that is widely found in neuron cell membranes. DHA can act as an antioxidant through the mechanism of suppressing pro-oxidant activity by upregulating genes encoding cytoprotective antioxidant proteins such as heme oxygenase 1 (HO-1) and glutathione peroxidase (GPx). Supplementation with the n-3 PUFA, DHA, suppressed production of 8-isoprostane, the gold standard biomarker of oxidative stress, and a specific marker of lipid peroxidation 21, in monocyte-derived macrophages, obtained from patients with abdominal aortic aneurysm. In addition, DHA increases GPx activity in macrophages [16].

Other researchers have proven that DHA protected the cells from $\mathrm{H}_{2} \mathrm{O}_{2}$-induced oxidative damage. In particular, pre-treatment with DHA can 
reduce the high levels of intracellular ROS associated with $\mathrm{H}_{2} \mathrm{O}_{2}$-induced oxidative stress, increased the intracellular levels of enzymatic antioxidants SOD and GPx, and augmented the intracellular levels of reduced glutathione and ascorbic acid, while it reduced the MDA levels under conditions of oxidative stress, upregulated the expression of nuclear factor (erythroid-derived 2)-like 2 (NFE2L2) and its downstream target protein, $\mathrm{HO}-1$. It was suggesting that DHA was able to prevent $\mathrm{H}_{2} \mathrm{O}_{2}$-induced oxidative damage to PC12 cells, which is attributed to its antioxidant and anti-apoptotic effects through the regulation of NFE2L2/HO-1 signaling [17]. Several studies show that the DHA diet increases the expression of mRNA catalase and GPx in the muscles, brain, and liver. DHA inhibits the neurodegenerative process by increasing antioxidant activity [18]. By increasing SOD and catalase enzymes, the free radical reaction products can be suppressed. This is evident in Figures 2 and 4 where the mean levels of peroxide and MDA in the P3 group were lower than in the other treatment groups.

As shown in Figures 1-4, the mean levels of SOD, peroxide, catalase, and MDA in the P4 and P5 groups were significantly different from the undernutrition (KP) group. This shows that the administration of seluang fish is able to overcome the oxidative stress that occurs in the brains of undernourished rats, although the potency is not as large as the combination of EPB and DHA.

In Triawanti et al., administration of seluang fish from South Kalimantan can improve brain oxidative stress in malnourished rats with lower mean peroxide and MDA levels than the group given placebo [4]. Seluang fish contain high protein and complete essential amino acids, including cysteine of $0.32 \mathrm{mg} / 100 \mathrm{~g}$. Cysteine is required for the synthesis of the enzyme GPx [19]. In addition, seluang fish also contain DHA of $1.04 \mathrm{mg} / 100 \mathrm{~g}$. Protein is needed to synthesize antioxidant enzymes and immunoglobulins. Under conditions of undernutrition, the synthesis of antioxidant enzymes, albumin, and immunoglobulins is disrupted, making it easy for infections to occur which stimulates nitric oxide (NO) synthase activity which results in increased free radicals. Therefore, adequate intake of animal protein is needed to provide exogenous enzymatic antioxidants. Meat protein is thought to be a good source from which to obtain antioxidant peptides, because meat proteins contain essential amino acids in high availability that is not usually found in plant proteins, such as methylhistidine and hydroxymethyllysine. The well-known antioxidant peptides of carnosine and anserine exist endogenously in muscle tissue, acting as free radical scavengers and metal ion chelators. Tripeptides with Trp and Tyr residue at the C-terminus could exert strong radical scavenging activities. Hydrophobic amino acids, such as Phe, Tyr, and Trp as hydrogen donors, could increase the presence of peptides at the water-lipid interface and then access to scavenge free radicals from the lipid phase. There are two acidic amino acids of aspartic acid (Asp) and glutamic acid (Glu) and three basic amino acids of arginine (Arg), lysine (Lys), and His utilized carbonyl and amino groups in the side chain which functions as chelators of metal ions. Cysteine also contributed to antioxidant potential because the sulfhydryl in the $\mathrm{R}$ groups could act as radical scavenger with reducing power. In the aforementioned synthetic peptides, Cyscontaining tripeptides showed strong scavenging ability on peroxynitrite [20].

There are two main mechanisms by which antioxidant molecules can deactivate free radicals: Hemolytic or hydrogen atom transfer (HAT) and singleelectron transfer (SET). The two mechanisms may occur in parallel, but one can dominate depending on the structure of the antioxidant peptide and the type of assay that will influence the solubility and partition coefficient. Tyrosine-containing peptides can act mainly through a HAT mechanism while cysteine, tryptophan, and histidine peptides act mainly through SET mechanisms. The proton can be directly transferred between the reacting molecules or can be involved in a solvent assisted proton loss depending on $\mathrm{pH}$ and acid-base properties. Radicals of antioxidant peptides have a significantly longer life than hydroxyl and peroxyl radicals produced in foods and during oxidative stress [21].

\section{Conclusion}

Based on the research that has been done, it can be concluded that the administration of a combination of $70 \%$ ethanol extract of pasak bumi $15 \mathrm{mg} / \mathrm{kg} \mathrm{BW}$ and DHA $1 \mathrm{mg} / \mathrm{kg}$ BW can improve oxidative stress in the brain of undernourished rats better than the only single administration of EPB $15 \mathrm{mg} / \mathrm{kg}$ BW, DHA, seluang fish, or the combination of $70 \%$ extract ethanol $15 \mathrm{mg} /$ $\mathrm{kg}$ BW pasak bumi and seluang fish. The combination of EPB $15 \mathrm{mg} / \mathrm{kg} / \mathrm{BW}$ and seluang fish improved brain oxidative stress in undernourished rats better than only given EPB $15 \mathrm{mg} / \mathrm{kg} \mathrm{BW}$ or seluang fish alone.

\section{References}

1. Wiktorska JA, Lewinski A, Sewerynek E. Effects of different antioxidants on lipid peroxidation in brain homogenates, induced by L-thyroxine administration in rats. Neuro Endocrinol Lett. 2005;26(6):704-8

PMid:16380675

2. Radosavljevic T, Mladenovic D, Ninkovic M, Vučević D, Boričić I, Ješić-Vukićević $\mathrm{R}$, et al. Oxidative stress in rat liver during acute cadmium and ethanol intoxication. J Serb Chem Soc. 
2012;77(2):159-76.

3. Khare M, Mohanty C, Das BK, Jyoti A, Mukhopadhyay B Mishra SP. Free radicals and antioxidant status in protein energy malnutrition. Int J Pediatr. 2014;2014:254396. https:// doi.org/10.1155/2014/254396

\section{PMid:24790610}

4. Triawanti T, Sanyoto DD, Nur'amin HW. Reduction of oxidative stress by seluang fish (Rasbora spp.) in brain of malnourished rats (Rattus norvegicus). Int J Food Eng. 2017;3(2):107-11. https://doi.org/10.18178/ijfe.3.2.107-111

5. Sanyoto DD, Asnawati A, Triawanti T. Effect of DHA suplementation on the MDA and SOD levels in protein malnurished rats. J Phys. 2019;1374:012050. https://doi. org/10.1088/1742-6596/1374/1/012050

6. Sakai C, Ishida M, Ohba $H$, Yamashita $H$, Uchida $H$, Yoshizumi M, et al. Fish oil omega-3 polyunsaturated fatty acids attenuate oxidative stress-induced DNA damage in vascular endothelial cells. PLoS One. 2017;12(11):e0187934. https://doi. org/10.1371/journal.pone.0187934

PMid:29121093

7. Triawanti T, Sanyoto DD, Noor MS. The supplementation of pasak bumi (Eurycoma longifolia Jack.) in undernourished rats to increase spatial memory through antioxidant mechanism. Clin Nutr Exp. 2020;33:49-59.

8. Suhartono E, Setiawan B. Model indeks peroksidatif dan indeks protein teroksidasi saliva penderita tuberkulosis paru berdasarkan lama pengobatan. JKM. 2010;2(9):118-23.

9. Wijeratne SS, Cuppet SL, Schlegel V. Hydrogen peroxide induced oxidative stress damage and antioxidant enzyme response in caco-2 human colon cells. J Agric Food Chem 2005;53(22):8768-74. https://doi.org/10.1021/jf0512003 PMid:16248583

10. Candan N. Changes in chlorophyll-carotenoid contents, antioxidant enzyme activities and lipid peroxidation levels in Zn-stressed Mentha pulegium. Turk J Chem. 2003;27(1):21-30.

11. Wang $X$, Michaelis EK. Selective neuronal vulnerability to oxidative stress in the brain. Front Aging Neurosci. 2010;2:12. https://doi.org/10.3389/fnagi.2010.00012

PMid:20552050

12. Mendez-Armenta M, Nava-Ruiz C, Juarez-Rebollar D, Rodriguez-Martinez E, Gomez PY. Oxidative stress associated with neuronal apoptosis in experimental models of epilepsy. Oxid Med Cell Longev. 2014;2014:293689. https://doi. org/10.1155/2014/293689

PMid:25614776

13. Perampalli T, Swami SC, Kumbar KM, Suryakar AN, Shaikh AK. Possible role of oxidative stress in malnourished children. Curr Pediatr Res. 2010;14(1):19-23.

14. Banjarnahor SD, Artanti N. Antioxidant properties of flavonoids. Med J Indones. 2014;23(4):239-44.

15. Wang $\mathrm{T}$, Li Q, Bi K. Bioactive flavonoids in medicinal plants: Structure, activity and biological fate. Asian J Pharm Sci. 2018;13(1):12-23. https://doi.org/10.1016/j.ajps.2017.08.004 PMid:32104374

16. Meital LT, Windsor MT, Perissiou M, Schulze K, Magee R, Kuballa A, et al. Omega-3 fatty acids decrease oxidative stress and inflammation in macrophages from patients with small abdominal aortic aneurysm. Sci Rep. 2019;9(1):12978. https:// doi.org/10.1038/s41598-019-49362-z

PMid:31506475

17. Clementi ME, Lazzarino G, Sampaolese B, Brancato A Tringali G. DHA protects PC12 cells against oxidative stress and apoptotic signals through the activation of the NFE2L2/ HO-1 axis. Int $\mathrm{J}$ Mol Med. 2019;43(6):2523-31. https://doi. org/10.3892/ijmm.2019.4170

PMid:31017264

18. Hashimoto M, Hossain S, Al Mamun A, Matsuzaki K, Arai $H$. Docosahexaenoic acid: One molecule diverse functions. Crit Rev Biotechnol. 2017;37(5):579-97. https://doi.org/10.1080/07 388551.2016 .1207153 PMid:27426008

19. Piste P. Cysteine-master antioxidant. Int J Pharm Chem Biol Sci. 2013;3:143-9.

20. Liu R, Xing L, Fu Q, Guang-Hong Z, Wan-Gang Z. A review of antioxidant peptides derived from meat muscle and by-products. Antioxidants 2016;5(3):32. https://doi.org/10.3390/ antiox5030032

PMid:27657142

21. Esfandi R, Walters ME, Tsopmo A. Antioxidant properties and potential mechanisms of hydrolyzed proteins and peptides from cereals. Heliyon. 2019;5(4):e01538. https://doi.org/10.1016/j. heliyon.2019.e01538

PMid:31183417 